\title{
Kesediaan Murid Mengaplikasikan Penggunaan Web 2.0 dalam Mata Pelajaran Sejarah di Sekolah Menengah
}

\section{(Students' Readiness Towards Applying Web 2.0 in Secondary School History Subjects)}

\author{
Emilda Balkis Ismail ${ }^{*}$ (D) Anuar Ahmad² \\ 1Fakulti Pendidikan, Universiti Kebangsaan Malaysia (UKM), 43600, Bangi, Selangor, Malaysia. \\ Email: emilda@chspj.edu.my \\ ${ }^{2}$ Fakulti Pendidikan, Universiti Kebangsaan Malaysia (UKM), 43600, Bangi, Selangor, Malaysia. \\ Email: anuarmd@ukm.edu.my
}

\section{CORRESPONDING \\ AUTHOR (*): \\ Emilda Balkis Ismail \\ (emilda@chspj.edu.my) \\ KATA KUNCI: \\ Kesediaan Murid \\ Web 2.0 \\ Mata pelajaran Sejarah \\ PdPc}

\section{KEYWORDS:}

Students' Readiness

Web 2.0

History Subjects

PdPc

\section{CITATION:}

Emilda Balkis Ismail \& Anuar Ahmad. (2022). Kesediaan Murid Mengaplikasikan Penggunaan Web 2.0 dalam Mata Pelajaran Sejarah di Sekolah Menengah. Malaysian Journal of Social Sciences and Humanities (MJSSH), 7(2), e001285.

https://doi.org/10.47405/mjssh.v7i2.1285

\begin{abstract}
ABSTRAK
Penggunaan Web 2.0 mempunyai keupayaan yang tinggi dalam mengubah teknik atau kaedah pembelajaran murid termasuk cara memperoleh maklumat berkaitan pembelajaran serta berinteraksi. Kajian ini bertujuan adalah untuk mengenal pasti kesediaan murid dalam mengaplikasikan penggunaan Web 2.0 sebagai platform pengajaran dan pemudahcaraan $(\mathrm{PdPc})$ mata pelajaran Sejarah. Teknik persampelan yang digunakan untuk mewakili populasi kajian ini adalah teknik persampelan rawak mudah. Seramai 285 orang murid sekolah menengah Tingkatan Satu dan Tingkatan Dua merupakan sampel kajian ini. Instrumen kajian ini yang digunakan adalah soal selidik skala likert empat mata yang mempunyai nilai kebolehpercayaan yang baik. Dapatan kajian menunjukkan bahawa tahap kesediaan murid dalam penggunaan aplikasi Web 2.0 berada pada tahap yang tinggi dalam kalangan murid sekolah menengah. Selain itu, dapatan kajian juga menunjukkan bahawa tiada perbezaan min tahap pengetahuan dan sikap murid terhadap penggunaan Web 2.0 dalam mata pelajaran Sejarah berdasarkan jantina dan umur. Implikasi kajian ini mencadangkan kepada guruguru untuk mempelbagaikan kaedah PdPc supaya proses pembelajaran Sejarah lebih menarik dan berkesan.
\end{abstract}

\section{ABSTRACT}

The use of Web 2.0 has a high ability to change the techniques or methods of student learning, including how to obtain information related to learning and interaction. This study aims to identify the level of readiness of students to apply the use of Web 2.0 as a platform for teaching and facilitation (PdPc) of History subjects. The sampling technique used to represent the population of this study was simple random sampling technique. A total of 285 Form One and Form Two secondary school students were the sample of this study. The instrument of this study is a 
four -point Likert scale questionnaire which has a good reliability value. The findings of the study show that the level of readiness of students in the use of Web 2.0 applications is at a high level among secondary school students. In addition, the findings also show that there is no difference in the mean level of knowledge and attitudes of students towards the use of Web 2.0 in the subject of History based on gender and age. The implications of this study suggest that teachers should diversify their PdPc methods to ensure that the History learning process is more interesting and effective.

Sumbangan/Keaslian: Sumbangan utama kajian ini adalah menyediakan maklumat yang berguna kepada penggubal kurikulum, para pentadbir dan guru-guru mengenai proses PdPc yang lebih berkualiti dan berkesan dengan mengintegrasikan Web 2.0 dalam kalangan murid sekolah menengah.

\section{Pengenalan}

Perkembangan teknologi sejajar dengan Revolusi Industri 4.0 (IR 4.0) membawa transformasi yang pesat dalam pelbagai bidang termasuk bidang pendidikan di Malaysia. Menurut Schwab (2016), IR 4.0 dengan menggunakan peralatan digital, produk yang digitalkan serta kesemua proses berkaitan pendigitalan merupakan suatu proses susulan revolusi tahap ketiga Kementerian Pendidikan Malaysia (KPM) (2013) menggariskan untuk memaksimumkan penggunaan ICT dalam usaha untuk meningkatkan kualiti pembelajaran di Malaysia menerusi Pelan Pembangunan Pendidikan Malaysia (PPPM 2013-2025). Menurut Ahmad Fakrudin, Wan Norina dan Nor Khayati (2019), teknologi yang diaplikasikan dalam proses PdPc menunjukkan satu peralihan baharu dalam teknik penyampaian pedagogi para pendidik. Kaedah PdPc dalam era IR4.0 perlu mempunyai fokus kepada konsep pembelajaran tanpa syarahan, penilaian tanpa peperiksaan dan ilmu tanpa sempadan yang lebih bersifat interaktif dan lebih berkesan Nor Azma (2018). Aplikasi Web 2.0 telah berkembang pesat sejajar dengan ledakan teknologi seperti merevolosikan kaedah PdPc membolehkan para guru dan murid berinteraksi secara dalam talian dan konsisten bagi mencapai matlamat pembelajaran.

Menurut Johan (2013), Web 2.0 didefinisikan sebagai generasi kedua World Wide Web yang membolehkan kolaborasi dan perkongsian maklumat di antara individu dalam talian. Secara amnya, ia adalah transformasi daripada laman web yang statik kepada laman web yang dinamik di mana pengguna boleh memberikan input dan memuat naik input ke dalam laman web. Penggunaan aplikasi Web 2.0 dalam PdPc dipengaruhi oleh konsep 'open educational resources' bermakna segala info dan aplikasi yang terdapat dalam Web 2.0 adalah percuma dapat digunakan tanpa halangan, malah pengguna boleh berinteraksi antara individu dengan individu yang lain di alam maya lebih sistematik (Ahmad Fakrudin, Wan Norina \& Nor Khayati, 2019). Menurut Mohd Sukki et al. (2013), bahan yang dihasilkan menggunakan aplikasi Web 2.0 bersifat efektif dan mampu memupuk minat dan motivasi murid-murid untuk mengikuti PdPc yang berterusan sama ada bersama guru atau secara kendiri. Persepsi dan kesediaan murid-murid sekolah menengah perlu diambil kira untuk memastikan penggunaan Web 2.0 dalam mata pelajaran Sejarah berada di landasan yang betul. Terdapat pelbagai kelebihan penggunaan aplikasi Web 2.0 dalam PdPc, namun demikian, penerimaan aplikasi Web 
2.0 dalam kalangan murid sebagai pengguna perlu dikaji (Lee \& Park, 2013). Hal ini penting bagi mengetahui keberkesanan penggunaan Web 2.0 semasa proses PdPc di sekolah atau secara maya.

\section{Pernyataan Masalah}

Penggunaan Web 2.0 merupakan antara pendekatan pembelajaran moden yang bersesuaian dengan arus teknologi masa kini. Aplikasi di bawah Web 2.0 juga dilihat dapat menarik minat murid-murid kerana paparan yang lebih interaktif untuk meningkatkan penguasaan dalam kesemua subjek yang perlu dipelajari di sekolah. Walau bagaimanapun, kajian berkaitan Web 2.0 dalam PdPc Sejarah terutamanya bagi murid sekolah menengah masih kurang dilaksanakan secara menyeluruh. Hal ini demikian mungkin disebabkan beberapa halangan yang memungkinkan murid-murid tidak mengaplikasikan penggunaan Web 2.0 sebagai kaedah pembelajaran mereka.

Oleh itu, pengkaji berpendapat dengan menggunakan Web 2.0 semasa proses PdPc terutamanya bagi mata pelajaran Sejarah mempunyai banyak manfaat kepada guru dan murid bersesuaian matlamat pembelajaran kendiri PPPM 2013-2025. Seterusnya, bahan dan sumber sejarah dalam talian dapat dioptimumkan bagi tujuan pembelajaran murid. Justeru, kesediaan murid mengaplikasikan Web 2.0 perlu dikaji untuk memastikan aktiviti pembelajaran bagi mata pelajaran Sejarah tidak hanya terhad pada waktu PdPc sahaja tetapi lebih bersifat fleksibel menerusi pembelajaran secara online.

Objektif dalam kajian ini adalah untuk:

i. Mengenal pasti tahap pengetahuan murid terhadap penggunaan Web 2.0.

ii. Mengenal pasti kemahiran murid terhadap penggunaan Web 2.0 dalam mata pelajaran Sejarah.

iii. Mengenal pasti sikap murid terhadap penggunaan Web 2.0 dalam mata pelajaran Sejarah.

iv. Mengenal pasti sama ada terdapat perbezaan min kemahiran murid terhadap penggunaan Web 2.0 dalam mata pelajaran Sejarah berdasarkan jantina.

v. Mengenal pasti sama ada terdapat perbezaan min sikap murid terhadap penggunaan Web 2.0 dalam mata pelajaran Sejarah berdasarkan umur.

\section{Sorotan Literatur}

\subsection{Penggunaan ICT dalam Pendidikan}

Dunia pendidikan di negara kita sedang mengalami peralihan dari masa ke masa. Menurut Md Sahir dan Mohd Ayub (2015), teknologi telah mengalami transformasi yang pesat sekaligus membawa kepada anjakan baharu terutamanya dalam sistem pendidikan. Perkara ini dapat dilihat dengan jelas melalui pembangunan pendidikan yang lebih memberi penekanan kepada budaya dan penguasaan di kalangan murid sekolah dalam bidang teknologi maklumat dan komunikasi (ICT) (Fadzil, 2015). Tambahan pula, penggunaan ICT pada masa kini dalam sesi pengajaran dan pemudahcaraan telah menjadi satu budaya dalam sistem pendidikan pada era ini (Abdul Rahman et al., 2015). Penggunaan teknologi untuk pembelajaran dalam talian semakin mendapat tempat khususnya dalam bidang pendidikan. Hal ini sekaligus dapat mewujudkan kepelbagaian dalam proses PdPc. Menurut kajian Hamimah dan Marlina (2017) pembelajaran secara dalam talian akan meminimumkan kebergantungan murid 
kepada guru dan lebih berfokuskan kepada pembelajaran berpusatkan murid selaras dengan keperluan Pembelajaran Abad ke-21 (PAK21). Pada era ini, penggunaan teknologi maklumat harus dimanfaatkan sebaiknya agar pengajaran tradisional dapat dimantapkan dengan menggabungjalinkan teknologi dalam PdPc. Perkara ini akan memberikan impak yang positif kepada murid untuk meneroka pembelajaran secara bebas. Walau bagaimanapun, sekiranya seseorang pendidik mempunyai kemahiran teknologi yang minimum, agak sukar bagi mereka untuk menggunakan aplikasi secara berkesan dalam konteks pengajaran.

Menurut Shah Rulbani, Mohd Isa dan Khadijah (2017) kekangan pembelajaran dalam talian berlaku akibat kurangnya kemahiran penggunaan teknologi oleh golongan pendidik. Oleh itu, sekiranya seseorang pendidik ingin mengintegrasikan teknologi dalam pengajaran maka harus mempunyai sekurang-kurangnya pengetahuan dan sedikit kemahiran dalam menggunakan aplikasi tersebut. Aktiviti pembelajaran yang bersifat fleksibel dan interaktif sangat penting dalam dunia pendidikan pada era ini untuk memudahkan murid meningkatkan ilmu pengetahuan semasa waktu persekolahan atau di luar waktu persekolahan. Murid-murid dapat mengulang kaji pelajaran di mana-mana atau pada bila-bila masa yang mereka inginkan (Zainul et al., 2017).

Menurut Zamri dan Nur Aisyah (2011), terdapat pelbagai perisian multimedia yang dibangunkan oleh golongan pendidik atau perseorangan sangat membantu sekaligus memudahkan sesi pengajaran guru daripada menggunakan strategi berpusatkan guru kepada strategi berpusatkan murid. Perkara ini secara tidak langsung membolehkan murid mendapatkan maklumat pada bila-bila masa tanpa perlu menunggu guru membuat sesi pengajaran di dalam kelas. Terdapat beberapa halangan dalam menyediakan Alat Bantuan Mengajar (ABM) serta beban kerja yang semakin meningkat menjadikan kekangan semasa proses menyediakannya. Tambahan pula, modal dan sumber kewangan yang besar perlu dikeluarkan untuk membeli ABM (Zamri, 2014). Halangan ini dapat diselesaikan dengan hanya menggunakan Web 2.0 dalam penyediaan ABM. Menurut Mohamed Amin (2013), aplikasi Web 2.0 merupakan satu transformasi daripada web bersifat statik kepada web bersifat dinamik serta lebih fleksibel. Guru dan murid boleh menggunakan aplikasi yang percuma tanpa batasan kecuali jika pengguna perlu membayar pakej khusus yang telah ditetapkan.

\subsection{Pengaplikasian Web 2.0 Dalam Pendidikan}

Aplikasi Web 2.0 sesuai diaplikasikan dalam penyediaan aktiviti pengukuhan seperti latih tubi untuk mengukur tahap kefahaman murid terhadap topik yang telah dipelajari semasa sesi pengajaran. Antara aplikasi yang boleh digunakan dalam Web 2.0 ialah Kahoot, Quizizz, Quizalize, Quizlet, Ed-Puzzle dan Plickers. Plickers merupakan aplikasi yang menggunakan internet dimana murid perlu menyediakan kad melalui LCD yang dipaparkan semasa berada di kelas. Aktiviti pengukuhan yang menggunakan aplikasiaplikasi yang terdapat dalam Web 2.0 memberikan motivasi kepada murid untuk bersaing bagi mendapatkan markah yang tinggi. Latihan ulang kaji seperti ini juga boleh digunakan sebagai kerja rumah dengan hanya memberikan link atau kod bagi menjawab latihan yang disediakan oleh guru. Guru boleh memberikan tempoh masa yang bersesuaian kepada murid untuk menyiapkan latihan pengukuhan tersebut dan murid boleh menyelesaikan soalan tersebut di mana-mana mereka berada berdasarkan tempoh masa yang telah ditetapkan oleh guru. Kepelbagaian aplikasi yang terdapat dalam Web 2.0 sangat praktikal untuk diterokai oleh warga pendidik khususnya guru 
bagi memastikan aplikasi yang dipilih sesuai digunakan dalam sesi Pdpc mengikut kesesuaian kandungan pelajaran dan tahap pencapaian murid. Hal ini kerana setiap murid mempunyai tahap pencapaian yang berbeza-beza dan guru boleh memilih kaedah pengajaran yang bersesuaian dengan tahap muridnya. Menurut kajian Hamdan et al. (2013) menyatakan beberapa kelebihan dalam penggunaan Web 2.0 dalam proses PdPc. Hasil kajian beliau menekankan kepada tiga aspek dalam meningkatkan; (i) potensi murid untuk penguasaan sesuatu kandungan pelajaran, (ii) maklum balas daripada murid-murid, dan (iii) interaksi yang berlaku dalam kalangan murid semasa aktiviti pembelajaran secara atas talian.

Secara umumnya, pendidikan pada masa kini tidak tertumpu hanya kepada pembelajaran konvensional yang hanya mementingkan kehadiran murid secara bersemuka di dalam kelas sebaliknya pembelajaran juga boleh terjadi secara dalam talian. Oleh yang demikian, pengaplikasian sistem penilaian murid secara berterusan perlu dilakukan dengan menggunakan pendekatan yang lebih relevan sesuai dengan perubahan teknologi masa kini. Di samping itu, warga pendidik perlu meningkatkan ilmu, kompetensi, keupayaan, kemahiran dengan kemahiran abad ke-21 yang salah satu yang perlu diberi penekanan adalah kemahiran maklumat, media dan teknologi (Raja Abdullah \& Daud, 2018) dalam usaha untuk menjadikan sesi PdPc lebih berkualiti dan berkesan. Para guru harus membuat perubahan sikap dan kesiapsiagaan untuk mengadaptasi senario baharu yang berlaku dalam dunia pendidikan dalam usaha melahirkan generasi yang celik teknologi maklumat. Sejarah merupakan mata pelajaran yang membosankan bagi sesetengah murid. Guru seharusnya memilih kaedah pengajaran yang berpusatkan murid dalam usaha untuk menarik minat mereka dalam mempelajari mata pelajaran Sejarah. Salah satu cara ialah dengan menggalakkan penggunaan Web 2.0 semasa sesi PdPc mata pelajaran Sejarah. Murid terlibat secara aktif dalam pembelajaran sama ada secara kendiri atau semasa pengajaran dalam kelas maka sesi pengajaran menjadi lebih menyeronokkan dan lebih berkesan.

Menurut Collins dan Halverson (2009), sekiranya murid diberikan peluang untuk memilih Alat Bantuan Mengajar yang mereka suka, tahap motivasi murid akan meningkat untuk mempelajari sesuatu topik pembelajaran. Sebagai contoh penggunaan Web 2.0 dalam sesi PdPc membolehkan murid memilih tahap pembelajaran mengikut kemampuan masing-masing. Dapatan kajian yang dijalankan oleh Chen (2014) menunjukkan bahawa pembelajaran realiti maya dengan menggunakan teknologi sangat diterima oleh murid dan memberikan kesan positif dalam pembelajaran kendiri mereka. Menurut kajian daripada Hazlina et al. (2017) menekankan seseorang guru perlu versatile dengan mempelbagaikan kaedah pengajaran semasa proses PdPc dalam usaha untuk menarik minat serta motivasi murid semasa pembelajaran bahasa asing. Konklusinya, kepentingan penggunaan Web 2.0 dalam usaha untuk menjadikan sesi pengajaran menjadi lebih interaktif dan berkesan serta menekankan strategi berpusatkan murid terutamanya bagi mata pelajaran Sejarah yang kurang diminati oleh murid.

\subsection{Latar belakang teori dan model}

Thorndike (1913) mempelopori teori pelaziman operan pada tahun 1874 sehingga 1949. Maksud pelaziman operan adalah pembelajaran yang melihat kesan daripada tingkah laku yang berkemungkinan menunjukkan tingkah laku tersebut sama ada diulangi, diteruskan atau dihentikan. Thorndike (1913) memberikan pendapat pembelajaran berlaku hasil gabungan daripada rangsangan dan gerak balas. Thorndike 
(1913) berpendapat bahawa jika terdapat hubungan antara rangsangan dan gerak balas akan mewujudkan kesan yang positif dan begitu juga sebaliknya. Oleh itu, teori ini sesuai digunakan oleh pengkaji kerana pengkaji ingin melihat tahap kesediaan murid dalam penggunaan Web 2.0 dalam mata pelajaran Sejarah. Sekiranya murid menunjukkan gerak balas yang positif maka murid bersedia untuk menggunakan Web 2.0 dalam pembelajaran dan pemudahcaraan begitu juga sebaliknya.

Kajian ini berdasarkan Model Penerimaan Teknologi (Technology Acceptence Model) oleh Davis (1989). Davis (1989) memberikan idea berkaitan TAM terhadap penerimaan pengguna terhadap teknologi komputer berpandukan justifikasi teori yang jelas. Matlamat asas TAM adalah untuk menunjukkan pengaruh pemboleh ubah luaran kepada kepercayaan dalaman, keinginan bertingkah laku dan sikap (Lu et al., 2003). Teori yang mendasari kerangka ini menunjukkan bahawa jika murid mahir dalam penggunaan internet seperti dalam penggunaan Web 2.0 maka ini akan membawa kepada pencapaian yang baik dalam sesuatu mata pelajaran.

\section{Metod Kajian}

Kajian tinjauan ini menggunakan satu set soal selidik yang diadaptasi daripada kajian Suzlina dan Jamaludin (2016). Soal selidik ini mengandungi empat bahagian: Bahagian A melibatkan demografi responden yang mengandungi maklumat seperti jantina dan umur; Bahagian B mengandungi 10 item berkenaan dengan tahap pengetahuan murid terhadap penggunaan Web 2.0 dalam mata pelajaran Sejarah. Bahagian C dan Bahagian D masing-masing mempunyai 10 dan 8 item yang akan mengukur kemahiran dan sikap murid terhadap penggunaan Web 2.0 dalam mata pelajaran Sejarah.

Jumlah item dalam instrumen kajian ini adalah sebanyak 28 item. Data yang telah diperoleh seterusnya dianalisis dengan menggunakan perisian SPSS versi 26 yang melibatkan analisis deskriptif dan analisis inferensi. Kajian ini disasarkan terhadap semua murid tingkatan 1 dan tingkatan 2 di sebuah sekolah menengah Petaling Utama iaitu seramai 1138 orang dan seramai 285 orang murid telah menjawab soal selidik melalui Google Form. Menurut Krejcie dan Morgan (1970), kajian yang mempunyai populasi seramai 1100 orang, bilangan sampel yang diperlukan dengan Confident Level 95\% dan Margin of Error 5\% adalah 285 sampel. Soalan-soalan yang disediakan berbentuk skala likert dengan menggunakan google form dibuat bagi melihat kesediaan murid dari aspek pengetahuan, kemahiran dan sikap murid terhadap penggunaan Web 2.0 dalam mata pelajaran Sejarah Sekolah Menengah. Bagi tujuan menganalisis data, skor min yang telah diperoleh seterusnya akan diinterpretasikan mengikut skala likert empat mata yang telah diadaptasi daripada Oxford (1990) serta Norasmah dan Salmah (2011).

\section{Hasil Kajian}

\subsection{Demografi Responden Kajian}

Taburan demografi responden di Bahagian A dianalisis menggunakan teknik deskriptif. Analisis dari teknik ini sangat membantu dalam memerihalkan profil responden seperti jantina dan umur murid. Data ini dianalisis melalui teknik kekerapan dan peratus (\%).

Analisis data pada Jadual 1 menunjukkan bahawa responden kajian ini terdiri daripada 115 orang murid lelaki iaitu $40.4 \%$ dan 170 murid perempuan iaitu sebanyak 59.6\%. 
Jadual 1: Profil Responden Berdasarkan Jantina

\begin{tabular}{lll}
\hline Jantina & Frekuensi & Peratus (\%) \\
\hline Lelaki & 115 & 40.4 \\
Perempuan & 170 & 59.6 \\
Jumlah & 285 & 100 \\
\hline
\end{tabular}

Analisis data pada Jadual 2 menunjukkan bahawa majoriti responden kajian terdiri daripada murid yang berumur 14 tahun iaitu sebanyak 171 orang $60.0 \%$ dan selebihnya berumur 13 tahun sebanyak 114 orang iaitu 40.0\%.

Data deskriptif ini dalam kajian ini untuk melihat kesediaan murid sekolah menengah. Kesediaan murid dikategorikan kepada 3 objektif utama iaitu untuk melihat aspek pengetahuan, aspek kemahiran dan aspek sikap murid dalam mengaplikasikan penggunaan Web 2.0 dalam mata pelajaran Sejarah.

Jadual 2: Profil Responden Berdasarkan umur

\begin{tabular}{lll}
\hline Umur & Frekuensi & Peratus (\%) \\
\hline 13 & 114 & 40.0 \\
14 & 171 & 60.0 \\
Jumlah & 285 & 100 \\
\hline
\end{tabular}

Jadual 3 merujuk kepada tahap pengetahuan murid menggunakan Web 2.0, skor min yang diperoleh secara keseluruhan untuk tahap kemahiran adalah 3.34 yang diklasifikasikan sebagai tinggi. Dalam jadual ini nilai min tertinggi ialah 3.57 iaitu murid sudah tahu menggunakan enjin pencarian (google search) untuk melayari maklumat. Dalam jadual ini juga didapati nilai min yang terendah ialah 2.91 di mana murid kurang memberi perhatian kepada peti e-mel yang dimiliki mereka. Dapatan kajian menunjukkan murid berpengetahuan dalam menggunakan Web 2.0 namun demikian murid kurang memberikan perhatian kepada peti e-mel.

Jadual 3: Tahap pengetahuan murid terhadap penggunaan Web 2.0

\begin{tabular}{lllll}
\hline Bil & Item Tahap Pengetahuan & $\begin{array}{l}\text { Skor } \\
\text { Min }\end{array}$ & $\begin{array}{l}\text { Sisihan } \\
\text { Piawai }\end{array}$ & Tahap \\
\hline 1 & $\begin{array}{l}\text { Saya menggunakan Internet untuk } \\
\text { membuat rujukan. }\end{array}$ & 3.43 & .644 & Tinggi \\
2 & $\begin{array}{l}\text { Saya kerap menggunakan maklumat dari } \\
\text { Internet. }\end{array}$ & 3.26 & .688 & Tinggi \\
3 & $\begin{array}{l}\text { Saya menggunakan enjin pencari (contoh } \\
\text { google search) untuk melayari maklumat. } \\
\text { Laman-laman web pendidikan banyak } \\
\text { membantu saya untuk mendapatkan } \\
\text { maklumat. }\end{array}$ & 3.57 & .599 & Tinggi \\
$5 \quad \begin{array}{l}\text { Saya mempunyai kemahiran dan } \\
\text { pengetahuan yang cukup dalam } \\
\text { penggunaan Internet. }\end{array}$ & 3.31 & .626 & Tinggi \\
\hline $\begin{array}{l}\text { Saya pernah menggunakan muat turun } \\
\text { (download) dan muat naik (upload) bahan }\end{array}$ & 3.52 & .648 & Tinggi \\
$\begin{array}{l}\text { untuk tujuan pembelajaran. } \\
\text { Peti e-mel sentiasa dikemas kini bagi } \\
\text { memastikan kelancaran capaiannya. }\end{array}$ & 2.91 & .938 & Sederhana \\
\hline
\end{tabular}




\begin{tabular}{lllll}
\hline & $\begin{array}{l}\text { Saya pernah menggunakan grafik dan } \\
\text { video melalui Internet }\end{array}$ & & & \\
8 & $\begin{array}{l}\text { Saya pernah menggunakan grafik dan } \\
\text { video melalui Internet }\end{array}$ & 3.23 & .717 & Tinggi \\
$9 \quad \begin{array}{l}\text { Saya kerap berkomunikasi dengan rakan- } \\
\text { rakan melalui laman sosial }\end{array}$ & 3.38 & .758 & Tinggi \\
$\begin{array}{l}\text { Saya tahu menggunakan maklumat dari } \\
\text { Internet untuk menambah ilmu } \\
\text { pengetahuan dan pembelajaran } \\
\text { Keseluruhan }\end{array}$ & 3.52 & .554 & Tinggi \\
\hline
\end{tabular}

Jadual 4 merujuk kepada tahap kemahiran murid menggunakan Web 2.0, skor min yang diperoleh secara keseluruhan untuk tahap kemahiran adalah 3.35 yang diklasifikasikan sebagai tinggi. Dalam jadual ini nilai min tertinggi ialah 3.58 iaitu murid boleh menggunakan enjin pencarian untuk melayari maklumat. Dalam jadual ini juga didapati nilai min yang terendah ialah 2.97 di mana murid kurang mahir mengintegrasikan pengetahuan mereka dalam mereka bentuk dan membina aktiviti pembelajaran menggunakan internet untuk meningkatkan pengetahuan mereka. Dapatan kajian menunjukkan murid berkemahiran dalam menggunakan Web 2.0 namun demikian murid kurang mahir dalam mereka bentuk dan membina aktiviti pembelajaran melalui internet.

Jadual 4 : Tahap kemahiran murid terhadap penggunaan Web 2.0

\begin{tabular}{|c|c|c|c|c|}
\hline Bil & Item Tahap Kemahiran & $\begin{array}{l}\text { Skor } \\
\text { Min }\end{array}$ & $\begin{array}{l}\text { Sisihan } \\
\text { Piawai }\end{array}$ & Tahap \\
\hline 1 & $\begin{array}{l}\text { Saya boleh menggunakan enjin pencari } \\
\text { untuk melayari maklumat. }\end{array}$ & 3.58 & .598 & Tinggi \\
\hline 2 & $\begin{array}{l}\text { Saya tahu menggunakan email untuk } \\
\text { berkongsi maklumat dengan rakan dan } \\
\text { guru. }\end{array}$ & 3.26 & .871 & Tinggi \\
\hline 3 & $\begin{array}{l}\text { Saya boleh menggunakan muat turun } \\
\text { (download) dan muat naik (upload) untuk } \\
\text { tujuan pembelajaran mata pelajaran } \\
\text { Sejarah. }\end{array}$ & 3.34 & .834 & Tinggi \\
\hline 4 & $\begin{array}{l}\text { Saya boleh menggunakan pelbagai } \\
\text { aplikasi seperti Quizizz Wordwall dalam } \\
\text { proses pembelajaran Sejarah dengan } \\
\text { menggunakan Internet. }\end{array}$ & 3.57 & .599 & Tinggi \\
\hline 5 & $\begin{array}{l}\text { Saya tahu menilai bila masa yang sesuai } \\
\text { untuk menggunakan Internet dalam } \\
\text { pembelajaran. }\end{array}$ & 3.20 & .713 & Tinggi \\
\hline 6 & $\begin{array}{l}\text { Saya mampu untuk mencari peluang } \\
\text { pembelajaran teknologi baru untuk } \\
\text { meningkatkan pengetahuan dan } \\
\text { kemahiran. }\end{array}$ & 3.31 & .710 & Tinggi \\
\hline 7 & $\begin{array}{l}\text { Saya boleh mereka bentuk dan membina } \\
\text { (sendiri atau kumpulan) aktiviti } \\
\text { pembelajaran yang dapat } \\
\text { mengintegrasikan pengetahuan saya } \\
\text { melalui Internet di dalam dan di luar bilik } \\
\text { darjah. }\end{array}$ & 2.97 & .811 & Sederhana \\
\hline 8 & $\begin{array}{l}\text { Saya mampu membina slaid sendiri untuk } \\
\text { tujuan pembentangan individu atau } \\
\text { secara kumpulan. }\end{array}$ & 3.42 & .777 & Tinggi \\
\hline
\end{tabular}


9 Saya tahu cara untuk berkongsi maklumat dengan rakan.

10 Saya mahir menggunakan Web 2.0 dalam tugasan kelas serta bekerjasama melakukan tugasan dan projek kumpulan dalam persekitaran internet.

Keseluruhan
3.54
.689
Tinggi
$3.34 \quad .628$
Tinggi

3.35

Jadual 5 merujuk kepada tahap sikap murid menggunakan Web 2.0, skor min yang diperoleh secara keseluruhan untuk tahap sikap adalah 3.25 yang diklasifikasikan sebagai tinggi. Dalam jadual ini nilai min yang tertinggi ialah 3.43 iaitu aplikasi seperti Facebook, Blog dan Twitter memudahkan orang ramai untuk meluahkan pendapat dan berkongsi maklumat serta aplikasi ini perlu digunakan dengan cara yang betul dan berhemah. Dalam jadual ini juga didapati nilai min yang terendah ialah 2.97 di mana murid kurang menggunakan e-mel sebagai alat perhubungan. Dapatan kajian menunjukkan murid mempunyai sikap yang positif dalam menggunakan Web 2.0 namun demikian murid kurang menggunakan e-mel sebagai alat perhubungan.

Jadual 5: Tahap sikap murid terhadap penggunaan Web 2.0

\begin{tabular}{|c|c|c|c|c|}
\hline Bil & Item Tahap Sikap & $\begin{array}{l}\text { Skor } \\
\text { Min }\end{array}$ & $\begin{array}{l}\text { Sisihan } \\
\text { Piawai }\end{array}$ & Tahap \\
\hline 1 & $\begin{array}{l}\text { Facebook, Blog dan Twitter menyediakan } \\
\text { ruang bagi orang ramai untuk berkongsi } \\
\text { maklumat dan pendapat, tetapi mesti } \\
\text { diguna dengan berhemah dan dengan cara } \\
\text { yang betul. }\end{array}$ & 3.43 & .800 & Tinggi \\
\hline 2 & $\begin{array}{l}\text { E-mail sangat baik untuk digunakan } \\
\text { sebagai alat perhubungan. }\end{array}$ & 2.97 & .915 & Sederhana \\
\hline 3 & $\begin{array}{l}\text { Kemahiran dalam bidang Internet yang } \\
\text { saya dapati sekarang amat mudah } \\
\text { dipelajari dan saya berminat untuk } \\
\text { mempelajari teknologi yang baharu. }\end{array}$ & 3.38 & .679 & Tinggi \\
\hline 4 & $\begin{array}{l}\text { Maklumat yang didapati dalam Internet } \\
\text { tidak semestinya tepat, terutama blog } \\
\text { peribadi orang lain. }\end{array}$ & 3.30 & .777 & Tinggi \\
\hline 5 & $\begin{array}{l}\text { Portal pendidikan membantu } \\
\text { pembelajaran mata pelajaran Sejarah saya. }\end{array}$ & 3.17 & .652 & Tinggi \\
\hline 6 & $\begin{array}{l}\text { Internet adalah bahan PdPc yang menarik } \\
\text { di dalam bilik darjah. }\end{array}$ & 3.31 & .705 & Tinggi \\
\hline 7 & $\begin{array}{l}\text { Kebanyakan teknologi Internet yang } \\
\text { diperkenalkan kepada saya dapat } \\
\text { mempelbagaikan kaedah pembelajaran } \\
\text { mata pelajaran Sejarah saya. }\end{array}$ & 3.20 & .665 & Tinggi \\
\hline \multirow[t]{2}{*}{8} & $\begin{array}{l}\text { Internet boleh menggantikan buku teks di } \\
\text { dalam bilik darjah. }\end{array}$ & 3.26 & .727 & Tinggi \\
\hline & Keseluruhan & 3.25 & & Tinggi \\
\hline
\end{tabular}

Jadual 6 menunjukkan perbezaan tahap kemahiran dalam kalangan murid sekolah menengah dalam mata pelajaran Sejarah berdasarkan jantina. Dapatan kajian mendapati bahawa tidak terdapat perbezaan yang signifikan bagi tahap kemahiran murid berdasarkan jantina $(\mathrm{t}=0.457, \mathrm{df}=283, \mathrm{p}>0.05)$. Min antara kumpulan menunjukkan min murid lelaki ialah $(\mathrm{M}=3.34, \mathrm{SP}=.496)$ manakala min bagi murid perempuan ialah $(\mathrm{M}=$ 3.36, SP=.477). Justeru, $\mathrm{H}_{01}$ gagal ditolak. Maka, dapat disimpulkan bahawa min 
kemahiran murid terhadap penggunaan Web 2.0 dalam mata pelajaran Sejarah berdasarkan jantina adalah sama antara murid lelaki dan murid perempuan dalam kajian ini.

Jadual 6: Analisis Ujian t Perbandingan Tahap Kemahiran Mengikut Jantina

\begin{tabular}{lllllll}
\hline Jantina & $\mathrm{N}$ & Min & SP & t & df & Sig \\
\hline Lelaki & 115 & 3.34 & .496 & 0.457 & 283 & .648 \\
Perempuan & 170 & 3.36 & .477 & & & \\
\hline
\end{tabular}

Jadual 7 menunjukkan perbezaan tahap sikap dalam kalangan murid sekolah menengah dalam mata pelajaran Sejarah berdasarkan umur. Dapatan kajian mendapati bahawa tidak terdapat perbezaan yang signifikan bagi tahap sikap murid berdasarkan umur $(\mathrm{t}=-$ $0.585, \mathrm{df}=283, \mathrm{p}>0.05)$. Min antara kumpulan menunjukkan min umur 13 Tahun ialah $(\mathrm{M}=3.23, \mathrm{SP}=.554)$ manakala min bagi umur 14 Tahun ialah $(\mathrm{M}=3.27, \mathrm{SP}=.491)$. Justeru, $\mathrm{H}_{\mathrm{o} 2}$ gagal ditolak. Maka, dapat disimpulkan bahawa min sikap murid terhadap penggunaan Web 2.0 dalam mata pelajaran Sejarah berdasarkan umur adalah sama antara murid lelaki dan murid perempuan dalam kajian ini.

Jadual 7: Analisis Ujian t Perbandingan Tahap Sikap Mengikut Umur

\begin{tabular}{lllllll}
\hline Umur & $\mathrm{N}$ & Min & SP & t & df & Sig \\
\hline 13 Tahun & 114 & 3.23 & .554 & -0.585 & 283 & .559 \\
14 Tahun & 171 & 3.27 & .491 & & & \\
\hline
\end{tabular}

\section{Perbincangan Kajian}

Dapatan kajian ini menunjukkan skor min kesediaan murid terhadap penggunaan Web 2.0 dalam mata pelajaran Sejarah diklasifikasikan sebagai tinggi. Dapatan ini sejajar dengan hasil dapatan daripada kajian Jeya dan Brandford (2019), NorZanira dan Hafizul (2019) serta kajian Haggag (2019) yang menyatakan bahawa penerimaan dan kesediaan murid terhadap penggunaan aplikasi teknologi dalam pembelajaran mata pelajaran pendidikan Islam, pendidikan tinggi dan bahasa Inggeris berada pada tahap yang tinggi.

Di samping itu, dapatan inferensi menunjukkan bahawa tidak terdapat terdapat perbezaan kesediaan penggunaan Web 2.0 dalam mata pelajaran Sejarah mengikut jantina. Hasil dapatan ini selari dengan hasil dapatan daripada kajian Muna dan Farrah (2017), Mohd Zulhasnan dan Fadli (2017), serta Rana dan Zamri (2017) yang melaporkan bahawa kekerapan menggunakan internet, jantina dan umur tidak membawa pengaruh kepada tahap kesediaan murid dalam PdPc.

Justeru, dapat disimpulkan bahawa murid-murid sekolah menengah terutamanya murid Tingkatan Satu dan Tingkatan Dua telah bersedia dalam penggunaan sebarang aplikasi teknologi yang dilaksanakan dalam proses PdPc mata pelajaran Sejarah. Walau bagaimanapun, berdasarkan hasil dapatan nilai min, murid perempuan telah menunjukkan kesediaan yang lebih tinggi berbanding dengan murid lelaki. Selain tu, murid perlu menyedari dan memahami pentingnya menguasai kemahiran Web 2.0 dalam proses pembelajaran mata pelajaran sejarah, bukan sahaja untuk pencapaian akademik mereka, tetapi juga membawa murid memberi keghairahan untuk memahami sesuatu kejadian atau masalah diri mereka dalam kehidupan sebenar. Kajian ini juga 
diharapkan dapat digunakan sebagai panduan dalam usaha untuk menambahbaikkan sistem pendidikan dalam proses PdPc terutamanya dalam mata pelajaran Sejarah.

\section{Kesimpulan}

Keseluruhannya, dapatan kajian ini menunjukkan bahawa tahap kesediaan murid Sekolah Menengah khususnya murid Tingkatan 1 dan Tingkatan 2 terhadap penggunaan Web 2.0 sebagai medium pembelajaran Sejarah berada pada tahap tinggi. Para guru khususnya guru Sejarah digalakkan untuk merancang dan mengintegrasikan penggunaan Web 2.0 dengan lebih berfokus bagi menjadikan proses PdPc semua mata pelajaran khususnya Sejarah menjadi lebih berkesan dan menarik. Hal ini selari dengan Pelan Pembangunan Pendidikan Malaysia 2013-2023 dalam anjakan ketujuh iaitu dengan memanfaatkan TMK dalam meningkatkan kualiti pembelajaran di Malaysia (KPM, 2013).

\section{Penghargaan (Acknowledgement)}

Terima kasih kepada penyelia Dr Anuar dan semua yang terlibat secara langsung dan tidak langsung dalam menjayakan kajian ini.

\section{Kewangan (Funding)}

Kajian dan penerbitan ini tidak menerima sebarang tajaan atau bantuan kewangan.

\section{Konflik Kepentingan (Conflict of Interests)}

Para penulis tidak mempunyai konflik kepentingan dalam menjalankan kajian dan penerbitan artikel ini.

\section{Rujukan}

Abdul Rahman, H., Zainal, N., \& Ab Karim, N. A. (2015). Keberkesanan Penggunaan ICT di dalam Pengajaran dan Pembelajaran Pendidikan Islam bagi Sekolah Kebangsaan Desa Pandan Kuala Lumpur. International Conference on Information Technology \& Society, Kuala Lumpur, Malaysia

Ahmad Fakrudin Mohamed Yussof, Wan Norina Wan Hamat dan Nor Khayati Basir. (2019). Penggunaan Aplikasi Web 2.0 dalam Proses Pengajaran dan Pembelajaran Kursus Mata Pelajaran UMUM (MPU) di Politeknik. E-Bangi Journal of Social Sciences and Humanities, 16(5), 1-13.

Collins, A., \& Halverson, R. (2009). Rethinking Education in the Age of Technology: The Digital Revolution and Schooling in America. Teachers College. Columbia University. New York, NY.

Chen, Y. L. (2014). A Study on Student Selfefficacy and Technology Acceptance Model within an Online Taskbased Learning Environment. Journal of Computers, 9(1), 3443.

Davis, F. D. (1989). Perceived usefulness, perceived ease of use and user acceptance of information technology. Mis Quartertly, 13(3), 319-339.

Fadzil, A. (2015). Penggunaan Aplikasi Multimedia Interaktif dalam Kemahiran Melukis,Mewarna dan Menganimasi Secara Digital. (Ijazah Doktor Falsafah). 
Hamdan, A., Din, R., Abdul-Manaf, S.Z., Mat-Salleh, N.S, Kamsin, I.F., Norman, H., Ismail, N.M., dan Mohamad-Zaid, A.S. (2013). Kelebihan dan Kekurangan Teknologi Web 2.0 dalam Model Integrasi E-Latihan Bermakna (I-MeT) dalam Kalangan Pelajar. 4th International Conference of Asean Studies on Integrated Education and Islamic Civilization UKM- UNIMED 9 - 10 December 2013, pp.1-10

Haggag, M. H. (2019). Using Google Classroom in enhancing communicative grammar use and attitudes of non-english specialized post graduates. European Scientific Journal, 15(1), 261-281.

Hamimah Salleh, \& Marlina Abdul Manaf. (2017). Pengintegrasian pembelajaran teradun dalam Pembelajaran Berasaskan Kerja (Work Based Learning). Jurnal Kejuruteraan, Teknologi dan Sains Sosial, 1, 16-23.

Hazlina Halim, Normaliza Abd Rahim \& Nor Shahila Mansor. (2017). Motivation and Strategies in Acquiring the French Language among Undergraduates in Universiti Putra Malaysia. Jurnal Linguistik, 21(2), 69-80.

Lee, H., \& Park, H.J. (2013). Testing the Impact of Message Interactivity on Relationship Management and Organizational Reputation. Journal of Public Relations Research, 25(2), 188-206.

Johan@Eddy Luaran. (2013). Pengintegrasian Web 2.0 dalam Pengajaran dan Pembelajaran subjek Sejarah dan Geografi. Seminar Pendidikan Sejarah dan Geografi (UMS, 29-30 Ogos 2013).

Jeya, A. K., \& Brandford, B. (2019). Google Classroom for mobile learning in higher education: modeling the initial peceptions of students. Education and Information Technologies, 1-25.

Kementerian Pendidikan Malaysia. (2013). Pelan Pembangunan Pendidikan Malaysia2013-2025. Putrajaya.

Krejcie, V. R., \& Morgan, W. D. (1970). Determining Sampel Size for Research Activities, Educational and Psychological Measurement. Duluth: University of Minnesota.

Lu, J., Yu, C., Liu, C., \& Yao, J. E. (2003). Technology acceptance model for wireless Internet. Internet Research: Electronic Networking Applications and Policy, 13, 206222.

Muna Ishak \& Farrah Wahida Abdullah (2017). Kesediaan pelajar semester satu jabatan Teknologi Maklumat dan Komunikasi (JTMK), Politeknik Seberang Perai (PSP) mengikuti pembelajaran berasaskan Blended Learning. Journal Kejuruteraan, Teknologi dan Sains Sosial, 1(1), 273-282.

Md Sahir, A., \& Mohd Ayub, A. F. (2015). Keberkesanan Penggunaan Video dalam Amali Masakan. International Journal of Education and Training, 1(2), 1-8.

Mohamed Amin Embi. (2013). Web 2.0 Interactive Tools : A Quick Guide. Bangi: UKM

Mohd Sukki Othman, Muhd Zulkifli Ismail \& Wan Nordin Wan Abdullah. (2013). Penggunaan ICT Dalam Pengajaran Bahasa Arab. Jurnal Linguistik, 17(2), 120127.

Mohd Zulhasnan Mat, Fadli Bacha \& Sharifuddin Rapin. (2019). Kesediaan pelajar dalam MPembelajaran bagi pengajaran dan pembelajaran di Kolej Komuniti Tawau, Sabah. Politeknik \& Kolej Komuniti Journal of Life Long Learning, 3(1), 103-111.

Norasmah, H. O., \& Salmah, I. (2011). Kecenderungan terhadap pemilihan kerjaya usahawan mengikut persepsi peserta skim usahawan siswa. Jurnal Teknologi, 56, 47-63.

Nor Azma, L. (2018). Pendidikan Tinggi 4.0. Retrieved April 15, 2018, from https://www.pressreader.com/malaysia/berita-harian malaysia/20180118/281947428261673

NorZanira Abdul Manan \& Hafizul Fahri Hanafi (2019). Google Classroom: Students acceptance using UTAUT model. JAPPA Journal: Journal of Applied Art, 1(1), 64-74. 
Oxford, R. L. (1990). Language Learning Strategies: What Everyteacher Should Know. New York, NY: Newburg House/ Harper \&Row.

Raja Abdullah Raja Ismail \& Daud Ismail (2018) Aplikasi Konsep 4C Pembelajaran abad Ke-21 Dalam Kalangan Guru Pelatih Pengajian agama Institut Pendidikan Guru Kampus Dato' Razali Ismail. Asian People Journal, 1(1), 45-65.

Rana Hamzah \& Zamri Mahamod (2017). Aplikasi Google Plus dalam pembelajaran dan pemudahcaraan (PdPc) Bahasa Melayu murid sekolah rendah. Prosiding Seminar Serantau, 651- 660.

Suzlina Hilwani Baharuddin \& Jamaludin Badusah (2016) Tahap pengetahuan, kemahiran dan sikap guru sekolah menengah terhadap penggunaan Web 2.0 dalam pengajaran bahasa Melayu. Jurnal Pendidikan Bahasa Melayu; Malay Language Education (MyLEJ), 6(2), 33-43.

Shah Rulbani Zakaria, Mohd Isa Hamzah, \& Khadijah Abdul Razak. (2017). Penggunaan ICT dalam Pengajaran dan Pembelajaran Pensyarah Pendidikan Islam di Politeknik Zon Selatan. Tinta Artikulasi Membina Ummah (TAMU), 3(1), 29-41.

Schwab, K. (2016). The Fourth Industrial Revolution. Geneva, Switzerland: World Economic Forum.

Thorndike, E. L. (1913). Education Psychology : Vol. 1: The Original Nature of Man. New York: Teachers College Press.

Zainul, A., Abdul Malek, A., \& Basharudin, N. A. (2017, 21-23 March 2017). Keberkesanan Penggunaan Video Pembelajaran Interaktif untuk Kursus Embedded System Application. Paper presented at the National Innovation and Invention Competition Through Exhibition (iCompEx'17), Politeknik Sultan Abdul Halim Mu'adzam Shah, Jitra, Kedah.

Zamri Mahamod \& Nur Aishah Mohamad Noor. (2011). Persepsi Guru Tentang Penggunaan Aplikasi Multimedia dalam Pengajaran Komponen Sastera Bahasa Melayu. GEMA OnlineTM Journal of Language Studies, 11(3), 163-177.

Zamri Mahamod. (2014). Kemahiran Bahasa Melayu untuk pelajar warganegara asing di IPTA dan IPTS Malaysia. Prosiding Seminar Pascasiswazah Pendidikan Bahasa Melayu dan Kesusasteraan Melayu Kali Ke-3, 1-6. Bangi: Penerbitan Fakulti Pendidikan, Universiti Kebangsaan Malaysia. 